Instructions for authors, subscriptions and further details:

\title{
The Role of Male Educators and the Challenges in Sexuality Education
}

\author{
Ana Lis Heredia Espinosa ${ }^{1}$ \& Adriana Rodríguez Barraza ${ }^{1}$
}

1) Universidad Veracruzana, México

Date of publication: October $21^{\text {st }}, 2021$

Edition period: June 2021 - October 2021

To cite this article: Heredia Espinosa, A \& Rodríguez Barraza, A. (2021). The Role of Male Educators and the Challenges in Sexuality Education. Masculinities and Social Change, 10 (3) 270-298.

https://doi.org/10.17583/MCS.2020.7973

To link this article: https://doi.org/10.17583/MCS.2020.7973

PLEASE SCROLL DOWN FOR ARTICLE

The terms and conditions of use are related to the Open Journal System and to Creative Commons Attribution License (CC-BY). 


\title{
The Role of Male Educators and the Challenges in Sexuality Education
}

\author{
Ana Lis Heredia Espinosa \\ Universidad Veracruzana
}

\author{
Adriana Rodríguez Barraza \\ Universidad Veracruzana
}

\begin{abstract}
Sex education is an educational curriculum area that represents a challenge for teachers, mainly if they are men. Therefore, the present study was carried out to identify the difficulties that male teachers face when addressing sex education with their students. It seeks to broaden the subject's understanding comprehensively and reflect on it in several dimensions, considering the actors involved: The State, the school, the role of teachers, and parents. A qualitative methodology was used, with a comprehensive-interpretive approach. Four public elementary teachers from the city of Veracruz, Mexico, participated. The instrument we used was a semi-structured interview. The findings were as follows: regarding their role as an educator, they consider that it is up to them to inform students on a scientific basis about sexuality; regarding their role in sex education, they think that they have the responsibility of reinforcing in the classroom the education that parents give their children at home. The challenges refer to the claims they receive from parents for talking about sexuality with kids and the lack of precision and depth in the content of the free textbooks regarding the matter. Finally, we conclude that sex education is a joint work in which the institutions' functions, both educational and family, are interrelated.
\end{abstract}

Keywords: Teachers, State, men, sexuality education, educator role, challenges. 
pp. $270-298$

\section{El Papel Educadores Varones y los Desafíos en la Educación Sexual}

Ana Lis Heredia Espinosa

Universidad Veracruzana

\author{
Adriana Rodríguez Barraza
}

Universidad Veracruzana

\section{Resumen}

La educación sexual es un área del currículo educativo que representa un reto para los maestros, particularmente si son varones. Por lo tanto, se realizó el presente estudio con el objetivo de identificar los desafíos a los que los docentes hombres se enfrentan al abordar educación sexual con sus estudiantes. Se busca ampliar la comprensión del tema de modo integral y reflexionarlo en varias dimensiones, considerando a los actores que intervienen: el Estado, la escuela, el papel de los profesores y los padres de familia. Se utilizó metodología cualitativa, con enfoque comprensivointerpretativo. Participaron 4 profesores de primarias públicas de la ciudad de Veracruz, México. El instrumento que utilizamos fue una entrevista semiestructurada. Los hallazgos fueron los siguientes: en cuanto a su papel como educador consideran que les corresponde informar con bases científicas sobre la sexualidad a los estudiantes; con respecto a su papel en la educación sexual piensan que tienen la responsabilidad de reforzar en clase la educación que los padres dan a sus hijos en casa. Los desafíos refieren a los reclamos que reciben de los padres por el hecho de hablar de sexualidad con los niños, y la falta de precisión y profundidad en el contenido de los Libros de texto gratuitos respecto a la materia. Finalmente, concluimos que la educación sexual es un trabajo conjunto en el que se interrelacionan las funciones de las instituciones, tanto educativas como familiares.

Palabras clave: Educadores/as, Estado, hombres, educación sexual, rol del educador/a, retos 


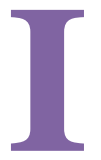

$\mathrm{t}$ is known that teachers play a fundamental role in the education of students since they are officially in charge of transmitting theoretical knowledge, skills, and values to children and adolescents.

In Mexico, most people who are dedicated to teaching in elementary schools are women, as a result of social construction in which, historically, they have been allowed to work in certain spaces, such as the school. Besides, there is the belief that women naturally have caregiving qualities, so society considers them more suitable for this work than men. This is why teaching can be considered a feminized profession (Buquet, 2006). The foregoing implies that various circumstances such as gender stereotypes, make it difficult for male teachers to carry out their work, especially when it comes to sex education.

In this sense, this study aims to identify the challenges that male teachers face when addressing sexuality issues with their students and analyze the role that they consider they have in the education of children and adolescents. Therefore, this article invites to reflect on the need for the school as an institution of the State, the teachers, and the parents to be clear about what they have to do, to allow each element of the system to carry out their functions in the best possible way and then, improve the educational process to achieve comprehensive development of kids (these functions are indicated later in tables 1,2 , and 3).

\section{Literature Review}

Here we present some recent research on the obstacles that teachers have faced when approaching sexual education to know how the subject has been explored and thus be able to expand the understanding of the phenomenon.

Quaresma da Silva (2014) in Brazil found that, out of a sample of 82 primary school teachers, made up of both men and women, $89.4 \%$ said they had difficulties working on sex education and pointed out that they did not feel prepared for this task. The results also indicate that sexuality education is not a cross-cutting issue; instead, teachers assume that they should address it only if students ask. Thus, children are in a vulnerable situation to problems like early pregnancy and sexually transmitted diseases. On the one hand, the state of Veracruz, where we did this study, in 2020 ranked first in the nation 
for HIV infection, with a total of 1,101 cases registered in the year (Ministry of Health, 2020). On the other hand, according to data from the National Strategy for Preventing Adolescent Pregnancy 2019, of the total births registered in the previous year, 156,757 were to mothers, ages ranging from 9 to 17 years. Likewise, the National Institute of Statistics, Geography and Informatics figures reveal that in the state of Veracruz, $18.6 \%$ of births come from adolescents under 20 years old (INEGI, 2020a). Furthermore, there is a high risk that most pregnancies in this age group are linked to maternal death, sexual abuse, or violent situations. (Instituto Nacional de las Mujeres, 2018). Sometimes, they feel ashamed to ask and prefer to remain with their doubts or seek information by other means.

Subsequently, García Villanueva, Ávila, Vargas, \& Hernández (2015) conducted in-depth interviews with four preschool teachers in Mexico City. They found that educational authorities and parents reinforce the stereotype of dominant masculinity (characterized by attributes that enhance reason, force, aggressiveness, and heterosexuality) by doubting the ability of men to serve as preschool teachers, labeling them as potential sexual abusers. These findings indicate that gender roles are rooted in the voice and expectations of the Mexican population and disseminated through social institutions like the State, the school, and the family.

In this regard, Burin (2009) refers that the classic terminology on femininity and masculinity is currently obsolete to describe the multiple modalities of construction of gender and masculine subjectivity associated with work careers and family life. She carried out a study with men whose mothers had studied and worked outside the home. She showed that, if the paternal and maternal models have a strict sexual division of work, the effects would be detrimental to acquiring an innovative masculine subjectivity, facing critical and changing working conditions. On the contrary, having flexible parental models regarding femininity and masculinity provides resources that expand and enrich male subjectivity, granting it a diversity of experiences that they seek to transmit to subsequent generations. These "degenderized" identifications would allow men to perform various tasks simultaneously (a capacity traditionally attributed to women), moderate the imperative of success, and improve the quality of life by enabling a space for intimate bonds (Burin, 2004). 
Likewise, being a preschool or elementary school teacher can represent a series of complex situations, since sometimes parents think that leaving a man in charge of their kids causes them concern. The current status of gender violence reinforces this conception. According to the United Nations (UN, 2019) and the National Institute of Statistics, Geography, and Informatics in Mexico (INEGI, 2019), women and girls represent a much smaller proportion of violence victims in general than men. However, they remain by far the highest-burden of crimes committed by intimate partners and close people, such as caregivers and even teachers.

Subsequently, Rosales \& Salinas (2017) collected four primary school teachers' testimony from the states of Quintana Roo and Yucatán: two 5thgrade and two 6th-grade teachers. Their results show that the textbooks' contents reduce sexuality to reproduction and do not incorporate the comprehensive sexuality education approach. Similarly, they found out that, usually, male teachers are afraid of giving fifth and sixth grade because they say that sometimes parents consider that they are flirting with girls and feel a particular fear of teaching those subjects.

Another relevant issue among the obstacles that teachers have in terms of sexual education is opposition. Also, Chandra Mouli, Garbero, Plesons, Lang \& Vargas (2018) refer that, throughout the history of education in Mexico, conservative parents supported by institutions such as the Church and other religious organizations have expressed their opposition to sex education. Despite the resistance, an interesting finding is that parents have not entirely rejected the concept of sex education; what they demand is that it occurs in schools since they consider that the authority they have in their children's education is displaced. These groups believe that school-based sex education can have consequences for childhood and adolescence, such as the risk of initiating sexual activity at an early age, masturbation, and homosexuality.

For their part, Figueroa \& Hernández (2018) conducted in-depth interviews with seven men who work in feminized professions, such as nursing and teaching. They emphasize that they came to perform them out of a mixture of economic expectations and personal development. They report that having had work experience from a close person in the feminized profession suggests an element that marked the future professional choice. They also found that older women and other men in their job discriminate against them. In the domestic sphere, they carry out care activities for their children and parents. 
As we can see, the studies highlight obstacles such as discrimination, the opposition of parents, the fear of talking about sexuality with the scholars, and not feeling prepared for the approach. However, this study includes teachers from the 4th grade of elementary school (who work with children aged 9 to 11) and knowing their experiences in this regard, both with girls, boys and parents. It is worth mentioning that the topics of sexual education appear since 4th-grade textbooks, provided by the Ministry of Public Education.

Now, we will present some theoretical references for a better understanding of the phenomenon. In the first place, we will address teaching in general as an activity in which the State determines the parameters that teachers must follow. Later, we will talk about sexual education, its characteristics, and legal basis; and finally, we will address the issue of obstacles in teaching, particularly those related to sexual education. So, this text seeks to broaden the understanding of the subject comprehensively and reflect on it in several dimensions, considering the actors involved:

- The State through its laws

- The school as a State institution

- The role of teachers and parents

\section{Teaching}

The family, the peer group, and the media fulfill educational functions. However, this study will focus on the school as an educational institution par excellence. Educational institutions are the places where culture centers on its influence since they transmit the knowledge necessary for individuals to regulate their actions and play a role in society. The education taught in schools presupposes pedagogical, ethical, and didactic models, from which the being, doing, and duty of the school, users, and teachers are determined. To differentiate it from that given at home, we could refer to it as school education and define it as the intentional action from the institutional point of view, aimed at providing learners with socially validated knowledge and values (Rosales, 2009).

Primary education is the basis of the National Educational System of Mexico. According to the National Occupation and Employment Survey results corresponding to the fourth quarter of 2019, there are 1,197,778 people employed as teachers in primary education. Of this total, practically half 
(50.4\%) are teaching in primary school, $25.9 \%$ are working in secondary school, and $23.7 \%$ in preschool (INEGI, 2020b).

These data allow us to see the importance of primary school teachers in Mexico. Referring to Echavarría (2003), the role of teachers is to transmit and develop content, skills, values, and attitudes in their students. Hence, the school has an ideological and socializing function, destined to adapt the young generations to society. Therefore, every educational proposal responds to an ethical and political conception destined to preserve or transform social reality.

However, through it, a series of gender stereotypes is also fostered. The conception of femininity and masculinity is reinforced, supported by specific characteristics, qualities, traits, and attributes, thus marking the duty of women and men. Thus, women are placed in the realm of emotions and affections and therefore are expected to be delicate, tender, dependent, willing to serve others, beautiful, and seductive. And, men are placed in the realm of power and rationality, and are expected to be intelligent, independent, decision-makers, combative, dominant, aggressive, and controlling. (Bustos, 1991).

Historically, the State intervenes in the school system through educational policies, which broadly refer to the government's action, or by public or private, national or international organizations, to guide the school's academic work in an institutional context. To better understand what the States' guidelines are regarding public education, Table 1 presents the themes and the main purposes based on the new educational model since 2016. 
Table 1

The axes of education and its main purposes in the New Educational Model.

\begin{tabular}{|c|c|}
\hline Axis & Main purposes \\
\hline School centered & $\begin{array}{l}\text { A new school culture. } \\
\text { The school as a community with management } \\
\text { autonomy. } \\
\text { Pedagogical assistance and supervision. }\end{array}$ \\
\hline Curricular design & $\begin{array}{l}\text { A flexible curriculum. } \\
\text { Focused on key learnings. } \\
\text { Articulation of emotions and cognition to guide } \\
\text { learning. } \\
\text { Learning environments. }\end{array}$ \\
\hline $\begin{array}{l}\text { Teacher } \\
\text { professional } \\
\text { training }\end{array}$ & $\begin{array}{l}\text { Define the mechanisms for admission, promotion, } \\
\text { recognition and permanence. } \\
\text { Update of the Normal Schools. }\end{array}$ \\
\hline $\begin{array}{l}\text { Inclusion and } \\
\text { equity }\end{array}$ & $\begin{array}{l}\text { Promotion of equal opportunities. } \\
\text { The school as a space that values diversity. }\end{array}$ \\
\hline
\end{tabular}

Source: Sectorial agenda for comprehensive sexuality education with emphasis on pregnancy prevention (2016).

In this sense, the Ministry of Public Education is in charge of the schools' supervision, the curricular approach, the training, and teachers' development. Regarding this last aspect, in Mexico, the Normal School is the central institution in charge of training teachers for the primary school level (preschool, elementary, and junior high school). This type of school was created in 1887 as a political and cultural project for the organization and homogenization of a training system for teachers in charge of bringing their knowledge, making the population literate, and spreading culture nationalist and promote the idea of progress to the most remote parts of the country.

They are vital for training teachers, mainly to enter professionally at the primary education level (preschool, elementary and secondary). The training approaches that circulate in the Normal Schools have gone in parallel with the national educational policies.

Through the Ministry of Public Education, the State is in charge of issuing the guidelines for the training of future teachers in these educational centers (Navarrete, 2015). However, according to the National Institute for the 
Evaluation of Education (Instituto Nacional de Evaluación de la Educación, 2012), various lags in children's learning are observed at the end of each educational level. For example, at the end of primary school, 27\% do not recognize the factors that alter the functioning of their body, nor can they relate the start of menstruation with the ability to reproduce. In this regard, the Ministry of Public Education published in 2020 a document entitled Framework of excellence in teaching and school management in Basic Education (SEP, 2020) that presents the profiles, domains, criteria, and indicators that are references for the admission processes, promotion, recognition, training, and support for teachers. This publication also explains the domains and criteria of the teacher profile, as indicated in Table 2 .

Table 2

Domains and criteria of the teaching profile according to the Ministry of Public Education (2020)

\begin{tabular}{|c|c|}
\hline Domains & Criteria \\
\hline $\begin{array}{l}\text { Teachers assume } \\
\text { their professional } \\
\text { work with adherence } \\
\text { to the philosophical, } \\
\text { ethical and legal } \\
\text { principles of Mexican } \\
\text { education. }\end{array}$ & $\begin{array}{l}\text { They assume the value of education as a } \\
\text { right of children and adolescents. } \\
\text { They work considering interculturality and } \\
\text { appreciation of diversity in all its } \\
\text { expressions. } \\
\text { They assume their responsibility to } \\
\text { participate in continuous training and } \\
\text { professional improvement processes. }\end{array}$ \\
\hline $\begin{array}{l}\text { Teachers know their } \\
\text { students to provide } \\
\text { them with } \\
\text { educational attention } \\
\text { with inclusion, equity } \\
\text { and excellence. }\end{array}$ & $\begin{array}{l}\text { They know their students to develop their } \\
\text { teaching in a pertinent and contextualized } \\
\text { way. } \\
\text { They develop strategies that allow them to } \\
\text { get to know their students and provide } \\
\text { them with equitable and inclusive } \\
\text { educational attention. } \\
\text { They encourage the participation of all } \\
\text { students and their learning beyond the } \\
\text { classroom. }\end{array}$ \\
\hline
\end{tabular}


Table 2 (Continued)

Domains and criteria of the teaching profile according to the Ministry of Public Education (2020)

$\begin{aligned} & \text { Teachers create } \\ & \text { favorable } \\ & \text { environments for the } \\ & \text { learning and } \\ & \text { participation of all } \\ & \text { children and } \\ & \text { adolescents }\end{aligned}$
$\begin{aligned} & \text { Teachers collaborate } \\ & \text { in the transformation } \\ & \text { and improvement of } \\ & \text { the school and the } \\ & \text { community. }\end{aligned}$

Source: Framework for excellence in teaching and school management in Basic Education (2020).

But also, teachers fulfill numerous roles with respect to their students. For Oeser (1967), the main roles of teachers over their students are as instructor, counselor, tutor, expert, judge, counselor and even friend. In this regard, Zembylas (2003), Day, Kington, Stobart \& Sammons (2005) have observed that teachers' identities are not only constructed by technical aspects but also by the interaction between their personal experiences and the institutional environment in which they are held. they develop daily. The variety of these roles and the complexity of their interrelationships make her task one of the most interesting and satisfying for herself, and one of the most frustrating and challenging. According to Rosales \& Salinas (2017), male teachers are usually afraid of giving fifth and sixth year because they say that sometimes parents consider that they are making girls fall in love, so they feel a certain fear to give those sexuality issues to girls.

Regarding the stereotypes of man's role, the masculine identity is constructed from his function of support and protector of the home and provider of the family's goods. He is socially assigned to finance the needs of the people who are part of his family, whom he considers his heritage 
(Jiménez, 2007). That is why men's work is assumed as a responsibility; being a provider is a meaning that is part of being a man and is part of the masculine identity. Work as a social practice becomes so important in the lives of men that it is one of the structuring axes of male identity; therefore, someone becomes a man when assuming responsibility as an employee (Salguero, 2006).

The ways teachers shape their professional identities are influenced by how they feel about themselves and their students. This professional identity helps them position themselves concerning their students and make appropriate and practical adjustments in their practice and their beliefs about students and their commitment (James, 2001; as cited in Day et al., 2005). An interesting aspect to consider has to do with the reasons for being a teacher. In men's case, a good part of them did not consider being an elementary school teacher as their first professional option. Instead, it was a decision made due to a series of circumstances, including having a fixed and stable salary. As García Villanueva, Ávila, Vargas \& Hernández (2015) point out, teaching seems to be a quick job with constant remuneration when being in a precarious economic situation.

\section{Sex Education}

In Mexico, sex education became compulsory and officially appeared for the first time in free textbooks back in 1974. Since then, several generations of free textbooks have passed, each with the respective modifications in its contents to respond to each moment's social demands.

People can study sex education from an informational or formative point of view. For López (2003), the informative models focus on the transmission of technical knowledge and objectives of sexuality, emphasizing the prevention of diseases and unwanted pregnancies. This classification includes models such as sexual education to avoid risks, health education, and sexual reproductive health. On the other hand, the formative models promote the integral sexual development of individuals because they encompass personal, emotional, and attitudinal aspects. Among the formative models are affectivesexual education, sentimental and erotic coeducation, and comprehensive sexuality education. Affective-sexual education can be defined as a gradual process that begins in the early years and occurs throughout life. It refers to the human need to establish links with other people, essential for survival and 
emotional stability. It also refers to our human nature as sexed beings, expressed in sexual identity, the awareness of being and belonging to sex, the sexual role, the expression of the personal way of living, the sexual desire, and the need for sexual satisfaction (Gómez, 2000; Carrera, Lameiras \& Rodríguez, 2007). According to Ramos (2007), Co-education is an instrument that allows education without discrimination based on sex, fostering an environment that understands and allows the existence of different ways of building as men and women. UNESCO (2018) defines comprehensive sexuality education as the process of preparing children with knowledge, skills, attitudes, and values to develop respectful social and sexual relationships, consider how choices affect their well-being and understand what their rights are throughout life to protect them.

In Mexico, article 30 of the General Education Law indicates that the curriculum must contain comprehensive and reproductive sex education, which implies the responsible exercise of sexuality, family planning, responsible motherhood and fatherhood, prevention of adolescent pregnancies, and sexually transmitted infections. Likewise, this same law establishes that in matters of healthy lifestyles and comprehensive and reproductive sexual education, the Ministry of Health may make suggestions about the Ministry of Education's content to determine what is appropriate.

For its part, article 71 of the General Health Law establishes that the Ministry of Health will provide, through the National Population Council, the national education system's advice for the development of educational programs on family planning and sex education. Despite having legal foundations and being compulsory in public schools, sex education continues to pose a challenge for teachers in the classroom due to imprecision in textbooks, complaints from parents, and their lack of support to the teachers.

\section{Challenges in Teaching}

Work is how people develop activities to satisfy their needs; it implies physical, mental, and emotional exhaustion (Salguero, 2009). In our context, it seems that we can consider the possibility that women carry out paid work as optional. For men, on the contrary, working and obtaining resources is assumed as a social mandate. Assuming the role of provider currently retains much weight on men, even when we know women can also work and get paid. 
Due to the validity of this imaginary social representation, unemployment damages mens' identity, even when their family group has other incomes. (Sicardi, 2009). In this sense, the world of work becomes a space in which men must have a place. Failure to achieve this goal can mean not being man enough and, therefore, is synonymous with unworthiness, disappointment, failure. In this regard, the notion of patriarchy has been dominant in the conceptualization of gender for a long time, emphasizing the social and cultural power exercised by men. The identification of men as patriarchs has left little space to analyze their costs and limitations and prevents recognizing the multiple and fragmented character of male identities (Pineda and Hernández, 2006); that means it contains accepting diversity and examining contradictions in the different groups of men.

On the other hand, teaching is a profession exercised mainly by women. According to INEGI (2020b), only 30\% of teachers working at the basic education level in Mexico are men. In this sense, it is understood that teaching is a feminized profession, which means that more than half of its participants are women (Buquet 2006). Gender roles are rooted in the Mexican population's voice and expectations, disseminated through social institutions, such as the State, the school, and the family. These reinforce the stereotype of dominant masculinity, attributing to those who exercise a profession considered female (for example, being a preschool or elementary school teacher) the label of gay or potential sexual abuser (García Villanueva et al., 2015). This has to do with the fact that the approach and physical contact with kids is considered natural in women, as an extension to their traditional role of caregivers; but, in men, it is viewed with suspicion since it implies that the reasons of physical contact are not necessarily for care, instead, of a sexual nature. In both senses, culture expects women to dedicate themselves more to teaching than men; complementarily, the dominant masculinity stereotype prevails.

In addition to this, sex education has always represented a delicate and difficult subject to tackle in general for teachers, but in particular, the difficulty increases when working at the primary level. As previously noted, it was made compulsory in Mexico in 1974. From then until now, parent organizations have expressed their opposition to this type of content being taught at school. One of them is the National Front for the family, an alliance of more than a thousand civil society institutions at the national level, which uses Catholic principles to defend institutions such as marriage between men 
and women and the so-called natural family as the basis of society. It was created in 2016 to request the recognition and protection of the family entity and the guarantee of parents' right to choose the type of education their children receive, mainly speaking of sexual education.

However, according to the General Education Law, parents have the right to associate and express their disagreements. Still, they also have to make sure their children receive preschool, elementary, junior high, and high school, whose contents, regulated by the State, necessarily include sexual education. Table 3 shows in detail the rights and obligations of parents emanating from the General Education Law (2019).

Table 3

Rights and obligations of parents and guardians according to the General Education Law (2019)

Rights

Enroll their children or wards in public school.

Participate with the school authorities in any problem related to the education of their children or wards.

Collaborate in the improvement of schools.

Become part of the parents' associations.

Know:

- The name of the teaching staff and employees assigned to the school in which their children are enrolled.

- The criteria and results of the evaluations of the school their children attend.

- The study plans and programs provided by the educational establishment, on which they may express their opinion.

- The budget assigned to each school.

- The academic situation and behavior of their children.

Express their disagreement with the corresponding educational authorities about any irregularity within the educational establishment where their children are enrolled. 
Table 3 (Continued)

Rights and obligations of parents and guardians according to the General Education Law (2019)

Obligations

1. Make their children or wards under eighteen years old, receive preschool, primary, secondary, upper secondary education.

2. Participate in their educational process by reviewing their progress, performance, and behavior.

3. Collaborate in the activities carried out by the educational institutions in which they are enrolled.

4. Inform the educational authorities of the changes that occur in the behavior and attitude of the students, so that the corresponding studies can be applied.

5. To attend the calls of the educational and school authorities related to the review of the progress, performance and behavior of the students.

6. Promote their participation in the practice of physical activities, recreation, sports and physical education.

Source: General Education Law (2019)

\section{Method}

We performed a descriptive study with a comprehensive-interpretive approach. The objective was to identify the obstacles that male teachers face when addressing issues of sexuality with their students due to gender stereotypes and the relationship between them and their parents. It is important to note that the Ethics Committee of the Institute of Psychological Research of the Universidad Veracruzana approved the research.

\section{Instrument and Procedure}

We conducted semi-structured interviews to determine the teachers' perspectives and obtain descriptions of their experiences in approaching sex education and the obstacles they face. Before each interview, we read an informed consent letter to each participant to sign, reiterating that we would record the audio. Still, it would be assigned a pseudonym so that they could not be identified. On average, the interviews lasted one hour. We had the 
interviews in various spaces inside schools. Subsequently, we transcribed each one of them verbatim.

\section{Participants}

The participants of this study were four teachers, ages ranging from 33 to 43 . One of them is a 4th-grade teacher, two are 5th-grade, and one is a 6th-grade teacher. They all teach in public schools and the morning shift. Another exciting piece of information was that, during the interviews, the teachers were asked if, at some point in their academic career, they had received sex education, to which they all answered no.

\section{Data Analysis}

Once we carried out the interviews, they were fully transcribed and analyzed based on the guidelines established by Kvale (2008) that consist of transcribing, coding, condensing, and interpreting the information until we confirm a definitive categorization. First, we assigned keywords to a text segment to allow subsequent identification. Hence, we grouped these codes into mutually exclusive categories. Categorization implies a broader and more systematic conceptualization. Therefore, grouped codes are reduced to a few categories (Kvale, 2008).

Three large categories were identified, from which other subcategories emerge, which are detailed below. The first category, called Role as an educator, refers to the role that the teachers assume as a professional in charge of educating young people. From this, four subcategories emerged, as seen in the following table. 
Table 4

Role as an educator.

\begin{tabular}{|c|c|}
\hline Subcategory & Description \\
\hline $\begin{array}{l}\text { Reinforcement } \\
\text { of parental work. }\end{array}$ & $\begin{array}{l}\text { Teachers believe that they have the responsibility and } \\
\text { commitment to reinforce the values and education that } \\
\text { parents give their children at home at school. }\end{array}$ \\
\hline $\begin{array}{l}\text { Training of } \\
\text { young children. }\end{array}$ & $\begin{array}{l}\text { Teachers consider it a privilege to have the opportunity } \\
\text { to train future generations in the first years of life. }\end{array}$ \\
\hline $\begin{array}{l}\text { Substitution of } \\
\text { parental figures. }\end{array}$ & $\begin{array}{l}\text { They believe that it is their responsibility to support } \\
\text { children by replacing the paternal or maternal image } \\
\text { that they do not have, since children take refuge in } \\
\text { them. }\end{array}$ \\
\hline $\begin{array}{l}\text { Support } \\
\text { personal } \\
\text { problems. }\end{array}$ & $\begin{array}{l}\text { They consider that their role is also to support children } \\
\text { who have personal problems, and to be their guide and } \\
\text { support in difficult situations. }\end{array}$ \\
\hline
\end{tabular}

The second category found in the study corresponds more specifically to the Teacher's role in sexuality education. In this regard, we identified two subcategories: one in which they assume that their role is as a counselor, and another. They are responsible for removing false beliefs about sexuality.

Table 5

Teacher's role in sexuality education

\begin{tabular}{ll}
\hline Subcategory & Description \\
\hline Counseling & $\begin{array}{l}\text { They consider that it is their responsibility to guide } \\
\text { students in their doubts about sexuality, but not to } \\
\text { educate, because they are educated at home. }\end{array}$ \\
\hline $\begin{array}{l}\text { Clarify wrong } \\
\text { beliefs }\end{array}$ & $\begin{array}{l}\text { Their role is also to remove false beliefs about sexuality, } \\
\text { through knowledge of science. }\end{array}$ \\
\hline
\end{tabular}

The third category corresponds directly to the Challenges that teachers have faced in the approach to sexual education. From it, four subcategories are derived, as seen in table 6 . 
Table 6

Challenges

\begin{tabular}{ll}
\hline Subcategory & Description \\
\hline Claims. & $\begin{array}{l}\text { They receive complaints from parents because they talk } \\
\text { about sexuality with children. }\end{array}$ \\
\hline $\begin{array}{l}\text { Lack of support } \\
\text { and supervision } \\
\text { of content. }\end{array}$ & $\begin{array}{l}\text { Irresponsible regarding the surveillance of children and } \\
\text { the consumption of sexual content on the internet. } \\
\text { Leaving children alone at home, unsupervised regarding } \\
\text { their activities and the people with whom they live. }\end{array}$ \\
\hline $\begin{array}{l}\text { Handling } \\
\text { textbooks. }\end{array}$ & $\begin{array}{l}\text { Lack of depth in the topics and of precision on the } \\
\text { approach of the contents. }\end{array}$ \\
\hline
\end{tabular}

\section{Findings and Discussion}

\section{Role as an educator}

The first category has four subcategories. The first is called Reinforcement of parental work, and it refers to the teacher's role as reinforcing the job of parents. Teachers consider that they have the responsibility and commitment to reinforce the values and education that parents give to their children at home. They state that their work must be done jointly with that of the parents, as mentioned in the following testimony:

I feel that we have a very great responsibility because society needs a lot of reinforcement of values, so I feel that there the teachers play an important part, of course, as long as we are reinforced with the parents, very important that reinforcement of the parents because one is here four hours with them, but most of the time they spend at home.

(Juan Carlos, 5th-grade teacher)

This speech coincides with what is established by the Professional profile, criteria, and indicators for personnel with technical, pedagogical advisory functions (SEP 2019). This document indicates that one of the functions of teachers is to collaborate with families in their children's educational process. This is related to the second subcategory, called Training of young children, which they consider a privilege and an opportunity to contribute to the development of children from their first years of life: 
I believe that teachers have the opportunity or privilege to be training future generations and here in the classrooms, in the early grades, is where a change can really be generated so that the future situation in society can be different. Sometimes we want adults to change, and that is very complex, but if we start from the base, I think we have that commitment, then that's how I take on teaching, like that responsibility or that commitment to improve things, and you get many positive experiences. (Daniel, 6th-grade teacher)

However, the third subcategory refers to how teachers come to assume that part of their role as a teacher is to act as parent figures:

\begin{abstract}
Also, sometimes you realize the shortcomings that some students have, and being the teacher allows you to support them, sometimes substituting a little for the paternal or maternal image that they do not have because they take refuge in you, or ask for advice or in some way they know that the guides and they pay attention to what you comment or take into account, then you influence them in some way. (Enrique, 4th-grade teacher)
\end{abstract}

This speech differs from what is indicated by the official guidelines (SEP, 2019) of what is incumbent on the teacher since it is indicated that the work that must be carried out is pedagogical so that it favors learning and the development of knowledge. The fourth subcategory refers to the role of the teacher as someone who provides support to students when they have personal problems, as well as being their guide and support in difficult situations.

It is a very important role. I am not the only person who comes here to cover a certain time. I am part of life, of the formation of each of my girls and boys, who have many emotional problems that, if I do not listen to them, they collapse. There have been cases of child maltreatment, abuse, who come and comment to me. (Enrique, 4thgrade teacher) 
Based on the Professional Profile, criteria, and indicators for personnel with technical, pedagogical advisory functions of the SEP (2019), one of the domains of the teacher profile is to know their students to provide them with educational attention with inclusion, equity, and excellence.

\section{Role of the teacher in sexuality education}

The second category found in the study corresponds more specifically to the Role of teachers in the sexuality education of young people. Regarding the first subcategory, the teachers consider that it is up to them to guide students in their doubts about sexuality, but not to educate, because they are educated at home, not at school:

For me, it is an orientation, not so much as education, because children are supposed to be educated at home, right? So, I feel that we should just guide the children, right? To have that openness to listen to them clarify doubts, because they have many doubts, which are not resolved at home, either for religious reasons, for questions of beliefs, or simply parents also sometimes because they do not know, so many children have many doubts, especially listening to them, giving them the confidence to that they externalize those doubts, and we can give them adequate guidance. (Juan Carlos, 5th-grade teacher)

On the other hand, teachers report that it is also their responsibility to remove false beliefs about sexuality through knowledge of science:

I like 5th grade because of the content covered here. More than anything, I focus on the subjects of Natural Sciences with the children because they have certain beliefs, and I like that their knowledge is a little more active, that they can touch and feel it. And, also, I like to remove false beliefs that they have: one regarding sexuality, and the other regarding science, because children at home have very restricted these issues. (Fernando, 5th-grade teacher). 


\section{Challenges}

The third category corresponds directly to the Challenges that teachers have faced in the approach to sexual education. From it, four subcategories are derived, as seen in table 6. The first subcategory, called Complaints, refers to the complaints that teachers receive from parents for addressing issues of sexuality in class. They comment that, for some parents, it is difficult to understand that this is something normal and that their children are at a stage of physical development where they need to know what is happening to their bodies:

It is a very difficult issue, for some parents, to understand that we are already talking about sexuality, that girls are about to start menstruating, and... I mean, it is normal! But the parents are reluctant to accept it. (Enrique, 4th-grade teacher).

This same teacher shares his experience with a parent who went to the school to complain about him for talking about sexuality in class. It should be noted that the Natural Sciences program in 4th grade includes knowledge of the genital organs as a topic, which implies calling each part of the body by name.

Of course, we have had problems, and it is not only my case. I have witnessed several parents who want to physically attack me and like this: Hey! What's wrong? They offend me, no matter how much I tell them: Don't worry, it's only a topic, they answer me: No, I don't want you to talk anything about sexuality to my daughter, or if it's called a vagina, no, no, no, no, and no! I see that at home. And I better answer them: Well, whatever you want. And better now to avoid problems because my work comes first, and I have a house and children to support... (Enrique, 4th-grade teacher).

This testimony reveals the concern generated in parents by the fact that a male teacher is in charge of a group (García Villanueva et al., 2015) since there is a belief that teachers seek to make female students fall in love (Rosales \& Salinas, 2017). That is why, on many occasions, teachers give in to the complaints of parents, as in the following case: 
I have obviously had parents who, by religion, say to me: Hey, you know what? My son is not going to participate, or I don't want my son to do this, but there is no problem. In the end, I give in to what they ask for, so they don't complain. (Juan Carlos, 5th-grade teacher).

The findings confirm the fact that parents often exercise their right to be involved in the student life of their children and express their disapproval about what they consider irregular. The second subcategory is called lack of accompaniment and supervision of content and refers to the lack of responsibility of caregivers regarding the surveillance of children and their consumption of sexual content on the Internet. Children sometimes have access to sexually explicit movies or videos because devices such as computers, tablets, and cell phones are shared by family members at home.

These children talk about anal sex, oral sex... They tell me: Teacher, I saw a movie. And I answer Son, why are you watching those kinds of movies? And they say: My dad left it there, on the computer. Hey, how is it possible! And you go and say something to the father, and he only answers: Well, it's my private life, why are you getting involved? And the parent is right again, what am I going to do? (Juan Carlos, 5th-grade teacher).

Regarding the influence of the media, one of the sources that children and adolescents resort to most are videos with pornographic content on the Internet. According to a study conducted in 2019 by the pornography website "Pornhub", Mexico ranks number 10 worldwide in visits to the site and number 1 in Latin America (El Universal, 2019). However, an interesting phenomenon that has occurred recently is that the traffic to this website from Mexico has not been the same since March 15, 2020, that is, since the Day of Sana Distancia was declared, which resulted in the suspension of classes and confinement in homes because as Enebral (2015) points out, the most chosen place for the consumption of pornographic material is the house itself or the bedroom. Therefore, in the following days, a significant increase was observed, reaching 24\% by March 17, just one day after the first cancellations of events, and the suspension of classes was announced in several states. For 
the announcement of phase II in Mexico on March 24, the increase was 29\%. In subsequent months, the Pornhub site registered a $40 \%$ increase in visits.

The third subcategory is called Abandonment, and it refers to leaving children alone at home, without supervision regarding their activities and the people with whom they live.

I have several students who are alone most of the time... Alone! I mean, who educates them? The TV. And the truth is that the media do not educate; I have the belief that these generations are the product of television, of the media. Open television is a harm, and if those children who are at home alone, watching $\mathrm{TV}$, consuming what the media projects them, for so long and without supervision, after a while they will see a drug dealer as a hero." (Juan Carlos, 5th-grade teacher).

Finally, the fourth subcategory is about Textbooks and refers to the lack of depth in the topics and of precision in the approach to the contents. In Mexico, the primary level educational curriculum is determined by the Ministry of Public Education. All the elementary schools in the country are based on it through textbooks that have been distributed free of charge since 1959 in the country's schools.

Now that I think about it more thoroughly, the issue that is not addressed, and that is related to sexuality, is gender diversity. Sexuality is discussed, and male and female roles are assumed, but the issue of sexual diversity is not touched. In other words, it does speak superficially in civic and ethical training that diversity must be respected, but what gender diversity is not yet emphasized in the books. (Daniel, 6th-grade teacher).

I feel that it lacks information, like that he needs to go deeper into the topic of sexuality, like that he touches it far above it... I mean, it is a subject seen very far above, and I think it should be more profound and give more information to the kids. (Juan Carlos, 5th-grade teacher).

Here it is verified once again that the contents of the textbooks reduce sexuality to reproduction and do not incorporate the integral education approach to sexuality (Rosales \& Salinas, 2017). In this regard, Palencia \& 
González (2015) point out the importance of school textbooks in the education of the general population, since, for most, they could be the only books they will read in their lives. It should be mentioned that, also, its contents are knowledge determined by the State under the educational policies of a certain moment. As Casanova, Díaz-Barriga, Loyo, Rodríguez \& Rueda (2017) pointed out, the current educational model refers to a series of values such as inclusion, equity, or humanism but it does not provide the guide to achieve them. Instead, it is limited to listing them as ideal approaches.

\section{Conclusions}

Throughout the article, it has broadened the understanding of the subject comprehensively and reflect on it in several dimensions, considering the actors involved:

- The State through its laws

- The school as a State institution

- The role of male teachers and parents

The lack of specificity in the Ministry of Public Education's official guidelines on what the teacher is expected to do hinders their work because instead of guiding them towards better performance, it presents an ambiguous panorama, on which each person decides the direction they want to take. It becomes more complex when it comes to sex education.

Historically, people have idealized the role of teachers, taking for granted that they must guide in a broad sense, fill the gaps in family education, and counteract the disintegration of society. At present, teachers are in a dilemma regarding the scope and limits of their profession and students' treatment. According to Ríos (2015), in education, little by little particular emphasis has been placed on the harmful effects of the hegemonic model of masculinity in schools in terms of harassment, violence, and school performance. It also refers to the need for the definition of educational actions by teachers with a dialogical foundation, including the perspective of new alternative masculinities.

Besides, teaching is socially considered a profession for women, so male teachers face rejection situations based on the prejudices around this work, such as questioning their ability to take care of care children or considering 
them as potential aggressors. Also, they often receive complaints, claims, and even threats from parents.

Therefore, we consider it necessary to precisely define both the functions of the teaching staff and those of the parents and guardians since the home is the first space where children acquire behaviors and knowledge that will be the basis of what they will later reproduce at school.

For this, the General Education Law can be a starting point, which indicates that teachers are responsible for designing activities and strategies to develop students' learning. Parents are responsible for accompanying their children and daughters in this process, monitoring their performance and behavior.

As can be seen, it is a joint work in which the institutions' functions, both educational and family, are interrelated. In this way, if children were to work in an articulated and comprehensive manner with the actors involved (the State, the school, the teachers, and parents), children could harmoniously develop their capacities in the different spaces they live in. That is why we consider that an adequate approach can transform the conditions in which the educational process occurs and reduce the challenges teachers face in the provision of sex education.

\section{References}

Arnaut. A. (1996). Historia de una profesión: los maestros de educación primaria en México, 1887-1994. Centro de Investigación y Docencia Económicas.

Buquet, A., 2006, Presencia de hombres y mujeres en la UNAM: una radiografía.

Burin, M. (2004). Género femenino, familia y carrera laboral: conflictos vigentes. Género, Trabajo y Familia. Subjetividad y procesos cognitivos 5. 48-75.

Bustos, O. (1991). Género y socialización: familia, escuela y medios de comunicación. En M. A. González-Pérez y J. Mendoza-García (eds.), Significados colectivos: procesos y reflexiones teóricas. México: Tec. de Monterrey/CIIACSO.

Cámara de Diputados del H. Congreso de la Unión (2019). Ley General de Educación. Retrieved from http://www.diputados.gob.mx/LeyesBiblio/pdf/LGE_300919.pdf 
Cámara de Diputados del H. Congreso de la Unión (2020). Ley General de Salud. Retrieved from http://www.diputados.gob.mx/LeyesBiblio/pdf/142_240120.pdf

Cardozo, A. (2017). La presencia de estrés en el profesorado según sexo y contexto laboral. Revista de Investigacion Psicologica, (18), 43-57. Retrieved from http://www.scielo.org.bo/scielo.php?script=sci_arttext\&pid=S222330322017000200005\&lng=es\&tlng=es .

Carrera, M., Lameiras M., \& Rodríguez, Y. (2007). Intervención y evaluación de un programa de educación afectivo-sexual en la escuela para padres y madres de adolescentes. Revista Diversitas, 3, (2). 191-202. http://www.usta.edu.co/otraspaginas/diversitas/doc_pdf/diversitas_6/vol. 3no.2/articulo_1.pdf

Casanova, H., Díaz-Barriga, A., Loyo, A., Rodríguez R, \& Rueda, M. (2017). El modelo educativo 2016: un análisis desde la investigación educativa. Perfiles educativos, 39(155), 194-205. Retrieved from http://www.scielo.org.mx/scielo.php?script=sci_arttext\&pid=S018526982017000100194\&lng=es\&tlng=es .

Chandra-Mouli, V., Gómez, L., Plesons, M., Lang, I., Corona Vargas, E. (2018). Evolution and resistance to sexuality education in Mexico. Global Health Science and Practice, 6(1):137-149. https://doi.org/10.9745/GHSP-D-17-00284 .

Day, C., Kington, A., Stobart, G., \& Sammons, P. (2005). The personal and professional selves of teachers: stable and unstable identities. British Educational Research Journal 4. 601-616.

Echavarría, C. (2003). La escuela: un escenario de formación y socialización para la construcción de identidad moral. Revista Latinoamericana de Ciencias Sociales, Niñez y Juventud, 1(2), 15-43. Retrieved May 21, 2021, from http://www.scielo.org.co/scielo.php?script=sci_arttext\&pid=S1692$715 X 2003000200006 \& \ln g=e n \& t \operatorname{lng}=e s$

El Universal 2019. México entre los países que más ven Pornhub. 12 de diciembre de 2019. Retrieved from https://www.eluniversal.com.mx/techbit/mexico-esta-entre-los-paisesque-mas-ven-pornhub

Enebral, A. \& Ramírez, M. V. (2015). Pornografía: Hábitos de consumo y su relación con la satisfacción sexual en adultos jóvenes. IV Jornadas de Actualización en Sexología del Instituto Andaluz de Sexología y Psicología. 53-65. 
Figueroa, J. G., \& Hernández, T. (2019). Hombres en profesiones de cuidado tradicionalmente feminizadas. Papeles de población, 25(100), 121151.https://doi.org/10.22185/24487147.2019.100.15

García Villanueva, J., Ávila, D., Vargas, M., \& Hernández, C. (2015). Acerca de la feminización de profesiones. Caso: la docencia en preescolar en la Cuidad de México. La ventana. Revista de estudios de género, 5(42), 129-151. Retrieved from http://www.scielo.org.mx/scielo.php?script=sci_arttext\&pid=S1405$94362015000200129 \& \operatorname{lng}=\mathrm{es} \& \ln \mathrm{l}=\mathrm{es}$.

Gómez, J. (2000). Educación afectivo sexual. Anuario de Sexología, 6, 4156.

Instituto Nacional de Estadística, Geografía e Informática (2020a). Censo de población y vivienda 2020. Retrieved from http://cuentame.inegi.org.mx/poblacion/escolaridad.aspx?tema=B Instituto Nacional de Estadística, Geografía e Informática. (2020b). Estadísticas a propósito del día del maestro. (Comunicado de prensa 215/20). Retrieved from https://www.inegi.org.mx/contenidos/saladeprensa/aproposito/2020/EAP Maestro2020.pdf.

Instituto Nacional de Estadística, Geografía e Informática (2019). Mujeres y hombres en México 2019. Retrieved from http://cedoc.inmujeres.gob.mx/documentos_download/MHM_2019.pdf

Instituto Nacional de Evaluación de la Educación (2012). Panorama Educativo de México 2010. Indicadores del Sistema Educativo Nacional. Educación Básica y Media Superior. Retrieved from https://www.inee.edu.mx/wp-content/uploads/2018/12/P1B109.pdf Instituto Nacional de las Mujeres. (2018). Estrategia Nacional para la Prevención del Embarazo en Adolescentes. Recuperado de https://www.gob.mx/cms/uploads/attachment/file/98138/ENAPEA_Mar zo.pdf

Jiménez, M. L. (2007). Algunas ideas acerca de la construcción social de las masculinidades y las feminidades, el mundo público y el mundo privado. En M. L. Jiménez \& O. Tena (eds.), Reflexiones sobre masculinidades y empleo (pp. 99-118). UNAM.

Kvale, S. (2008). Las entrevistas en investigación cualitativa. Madrid: Morata.

López, N. (2003). Curso de educación afectivo-sexual. Libro de teoría. España: Netbiblio. 
Navarrete, Z. (2015). Formación de profesores en las escuelas normales de México. Siglo XX. Revista Historia de la Educación Latinoamericana, 17 (25). 17-34. https://doi.org/10.19053/01227238.3805.

Oeser, O. A. (1967). Maestro, alumno y tarea. Argentina: Paidós.

Organización para la Cooperación y el Desarrollo Económico (2018). La OCDE sostiene que es necesario redoblar los esfuerzos para mejorar la equidad en la educación.

http://www.oecd.org/centrodemexico/medios/laocdesostienequeesnecesar ioredoblarlosesfuerzosparamejorarlaequidadenlaeducacion.htm

Palencia \& González (2015). Palencia, M. \& González, R. (2015). Libros escolares y políticas públicas de género: un estudio retrospectivo. Temas de educación, 21(1), 31-46

Pineda, J. \& Hernández, A. (2006). Retos de la equidad para los hombres. Nómadas 24 152-163.

http://nomadas.ucentral.edu.co/index.php/inicio/25-genero-y-politicaspublicas-desafios-de-la-equidad-nomadas-24/342-los-retos-de-laequidad-para-los-hombres

Quaresma da Silva, D. (2014). Tratamiento de la educación sexual en escuelas primarias en el sur de Brasil. Revista Cubana de Salud Pública, 40(4), 289-298. Retrieved from

http://scielo.sld.cu/scielo.php?script=sci_arttext\&pid=S0864$34662014000400005 \& \operatorname{lng}=\mathrm{es} \& \operatorname{tln} \mathrm{g}=\mathrm{es}$.

Ramos, C. (2007). El pensamiento de los aprendientes en torno a cómo se aprende una lengua: dimensiones individuales y culturales. Madrid, España: Ministerio de Educación y Ciencia.

Ríos, O. (2015). Nuevas masculinidades y educación liberadora. Intangible Capital, 11(3),485-507.

https://www.redalyc.org/articulo.oa?id=54941394011

Rosales, M. Á. (2009). La formación profesional del docente de primaria. México D.F, Mexico: Plaza y Valdés, S.A. de C.V. Retrieved from https://elibro.net/es/ereader/bibliotecauv/38846?page=21.

Rosales, A., \& Salinas, F. (2017). Educación sexual y género en primarias mexicanas ¿qué dicen los libros de texto y el profesorado? Revista Electrónica Educare, 21 (2), 1-21.

Salguero, A. (2006). Identidad, responsabilidad familiar y ejercicio de la paternidad en varones del Estado de México. Papeles De PoblacióN, 12(48). https://rppoblacion.uaemex.mx/article/view/8675

Secretaría de Educación Pública SEP (2018). Agenda sectorial para la educación integral en sexualidad con énfasis en la prevención del 
298 Heredia \& Rodríguez - Identidad de Género de Jóvenes Trans

embarazo en adolescentes. Retrieved from

https://www.gob.mx/cms/uploads/attachment/file/321436/SEP_ENAPEA 190318_3.pdf .

Secretaría de Educación Pública SEP (2019). Marco para la excelencia en la enseñanza y la gestión escolar en la Educación Básica. Retrieved from http://file-system.uscmm.gob.mx/2020-

2021/compilacion/PERFIL_PROFESIONAL_ATP_EB_2019_130320.pd $\mathrm{f}$

Secretaría de Salud. (2020). Informe Histórico al 4º Trimestre de VIH 2020.

Sistema de Vigilancia Epidemiológica de VIH. Recuperado de https://www.gob.mx/cms/uploads/attachment/file/622468/VIHSida_4toTrim_2020.pdf

Sicardi, L. (2009). Trabajo y subjetividad masculina. La Manzana 7(4). http://www.estudiosmasculinidades.buap.mx/num7/trabajo.html

Solís, A. (2016). La perspectiva de género en la educación. En J.A. Trujillo y J.L. García (eds.), Desarrollo profesional docente: reforma educativa, contenidos curriculares y procesos de evaluación (pp. 97-107), México: Escuela Normal Superior.

UNESCO (2018). Orientaciones técnicas internacionales sobre educación sexual. Un enfoque basado en la evidencia. Retrieved from http://unesdoc.unesco.org/images/0026/002653/265335s.pdf.

United Nations (2019). Global Study on Homicide. Gender-related killing of women and girls. Retrieved from https://www.unodc.org/documents/data-andanalysis/gsh/Booklet_5.pdf?fbclid=IwAR1mbvHzAjSoFnz8STSBAFdjB FQdlYP7Yum5MXJby3_pKsEGUFLfJLmwALk .

Zembylas, M. (2003). Emotions and Teacher Identity: A poststructural perspective, Teachers and Teaching: Theory and Practice, 9(3). 213-238. http://dx.doi.org/10.1080/13540600309378.

Ana Lis Heredia Espinosa is professor at the Faculty of Psychology at Universidad Veracruzana, Mexico.

Adriana Rodríguez Barraza is a full-time researcher at the Institute of Psychological Research at Universidad Veracruzana, Mexico.

Contact Address: Direct correspondence to Ana Lis Heredia Espinosa. Faculty of Psychology, Universidad Veracruzana, Mexico. Address: 20 de noviembre Avenue, no number, 91910 Veracruz, Mexico.email: aheredia@uv.mx 